\title{
SPATIAL VARIABILITY OF MICROBIAL BIOMASS AND ORGANIC MATTER LABILE POOLS IN A HAPLIC PLANOSOL SOIL (1)
}

\author{
DIEGO CAMPANA LOUREIRO $\left({ }^{2}\right)$; HELVÉCIO DE-POLLI $\left({ }^{3}\right)$; MARCOS BACIS CEDDIA $\left({ }^{2}\right)$; \\ ADRIANA MARIA DE AQUINO (3)
}

\begin{abstract}
The objective of this work was to study the spatial variability of soil microbial biomass (SMB) and labile soil organic matter pools (labile SOM), under different management systems and plant cover. The experiment was conducted in a Haplic Planosol soil on an Integrated Agroecological Production System (SIPA), in Seropédica, Rio de Janeiro. The evaluated management systems were: alley cropping, pasture, and bush garden, the late one was used as reference area. Three grids of regular spacing of $2.5 \times 2.5$ meters were used for sampling, consisting of 25 georeferenced points each, where soil samples were taken at $0-10 \mathrm{~cm}$ depth. The following labile constituents of soil organic matter were determined: free light fraction (FLF), water soluble C and N, C and N of SMB (SMB-C and SMB-N), and glomalin content. The textural fractions (sand, silt, and clay), $\mathrm{pH}$ in water, and chemical attributes (organic $\mathrm{C}$, total $\mathrm{N}, \mathrm{Ca}, \mathrm{Mg}, \mathrm{Al}, \mathrm{P}, \mathrm{K}$, and CEC-cation exchange capacity) were also determined. The areas of alley cropping and pasture showed spatial dependence to the attributes of SOM. The occurrence of high spatial dependence for the attributes associated to microbial biomass in the alley cropping system (C, FLF, SMB-N and respiration), probably was due to external factors related to management, such as: intensive rotational cropping system, diversity of crops and different inputs of organic matter to soil such as pruning material and organic compost.
\end{abstract}

Key words: organic carbon, geoestatistic, glomalin, precision agriculture.

\section{RESUMO}

\section{VARIABILIDADE ESPACIAL DA BIOMASSA MICROBIANA E COMPARTIMENTOS LÁBEIS DA MATÉRIA ORGÂNICA DE UM PLANOSSOLO HÁPLICO}

\begin{abstract}
O objetivo do trabalho foi estudar a variabilidade espacial da biomassa microbiana do solo (BMS) e dos constituintes lábeis da matéria orgânica do solo (MOS), sob diferentes sistemas de manejo e cobertura vegetal. O experimento foi instalado em um Planossolo Háplico no Sistema Integrado de Produção Agroecológica (SIPA), em Seropédica (RJ). Os sistemas de manejo avaliados foram: cultivo em aléias, pastagem e, horto florestal como área de referência. Para a amostragem utilizaram-se três grades regulares com espaçamento de 2,5 x 2,5 metros, composta de 25 pontos georreferenciados para cada grade, onde se coletou amostras de terra na profundidade de $0-10 \mathrm{~cm}$. Em cada amostra determinaram-se os seguintes constituintes lábeis da MOS: fração leve livre, formas de C e N solúveis em água, C e N associado à BMS e teor de glomalina. Determinaram-se também as frações granulométricas areia, silte, argila, umidade gravimétrica, bem como os atributos químicos de rotina. Somente as áreas de cultivo em aléias e pastagem tiveram dependência espacial para os atributos da MOS. A ocorrência de maior dependência espacial dos parâmetros associados à BMS nas aléias (C, fração leve livre da MO, BMS-N e respiração), foi em decorrência de, provavelmente, de fatores extrínsicos relacionados ao manejo, tais como: intensa rotação e diversidade de culturas e aporte diferenciado de adubos orgânicos (material de poda e aplicação de compostos orgânico).
\end{abstract}

Palavras-chave: carbono orgânico, geoestatística, glomalina, agricultura de precisão.

(1) Received for publication in September 18, 2008 and accepted in February 3, 2010.

( $\left.{ }^{2}\right)$ Universidade Federal Rural do Rio de Janeiro. E-mail: campanaloureiro@gmail.com; ceddia@ufrri.br $\left(^{*}\right)$ Corresponding author.

(3) Embrapa Agrobiologia, km 7, Caixa Postal 74.505, 23890-000 Seropédica (RJ).E-mail: depollih@gmail.com; adriana@cnpab.embrapa.br 


\section{INTRODUCTION}

Several studies in the literature show the importance of monitoring the quantity and quality of soilorganic matter (SOM) so as to produce more with less intensive use of land (SouzA et al., 2006; Hopmans et al., 2005; Moreira and Malavolta, 2004; D'ANDREA et al., 2004; Marchiori JuNIOR and MELO, 2000). The microbial activity of soil and the fractions of labile SOM are considered important indicators of the sustainability of management systems (Maluche-Baretta et al., 2006; Fraisse et al., 1999; Swezey et al., 1998).

Most studies related to soil micro-biota use quantitative attributes such as soil microbial biomass (SMB), respiration and metabolic quotient $\left(\mathrm{qCO}_{2}\right)$ to establish a systematic interpretation of the quality of SOM. Other attributes of promptly metabolized fraction of SOM such as glomalin content, soluble carbon source, and free light fraction also aid in the interpretation of SOM quality. The interpretation of the interactions of these attributes can provide an indication of changes in the environment due to management practice.

Another aspect related to the study of SMB is that in most cases data are analyzed by means of classical statistics (test of means, variance, and coefficient of variation) and it is assumed that the data show normal distribution and random variance (MARTINAZZO et al., 2007; Assisi Junior et al., 2003; MARCHIORI JuNIOR and MELO, 2000; Alvarenga et al., 1999). In general, soil attributes that are subject to temporal variation (microbial activity, moisture and soluble soil nutrients), are often subject to a high spatial variability (HALVORSON et al., 1997). In fact, attributes such as microbial biomass and labile fractions tend to an erratic behavior in the soil. However, in some cases, geostatistics analyses show spatial dependence for these attributes according to the system of management (StOYAn et al., 2000). El SEBAI et al. (2007) found spatial dependence for microbial biomass carbon in long term wheat cropping area.

According to CARVALHO et al. (2003), the spatial variability of soil attributes can be influenced by their intrinsic factors (soil genesis, geologic origen, topography, climate, biota and time) and the extrinsic factors, normally related to the practices of management. PAZ-GonZÁLEZ et al. (2000), studying the spatial variability of soil properties (organic matter, nitrogen, phosphorus, cation exchange capacity, $\mathrm{pH}$ in $\mathrm{H}_{2} \mathrm{O}$, sand, silt, clay and gravel) in different land uses (area of natural vegetation and crop land) found that the area of natural vegetation was more diversified, providing evidence that the deforestation and long term of cropping promoted change in the pattern of spatial variability and increased the homogeneity of some soil attributes. The cultivated area presented, as beneficial changes, higher $\mathrm{pH}$ and Olsen-P, however, the loss of organic matter by cultivation was far from deleterious, but causes a significant CEC decrease, which was found to be the most detrimental change for sustainable soil use.

Considering that the spatial variability is important for better understanding of the relationship between management and dynamics of soil organic matter, the objective of this work was to study the spatial variability of microbial biomass and labile constituents of soil organic matter under different management systems and plant cover.

\section{MATERIAL AND METHODS}

The study of soil microbial biomass (SMB) and labile constituents of soil organic matter (SOM) was held in a Haplic Planosol soil on a 15-year-old Integrated Agroecological Production System (SIPA), in Seropédica, Rio de Janeiro. The management systems evaluated were: alley cropping, pasture, and bush garden as a reference area. The alley cropping system was composed of Gliricidia sepium rows of six meters apart where, until 2004, were grown in between rows several crops such as lettuce, chive, spinach, radishes, ginger, corn, and common bean. From 2005 to this sampling time tropical flowers (Heliconiaceas, Musaceas and Zingiberaceas) and black pepper were introduced. The pasture area was established in 1997 with Transvala grass (Digitaria decumbens Stent cv. Transvala). The bush garden was established in 1950 with Acacia spp., Mimosa spp., Cassia fistula, Anadenanthera sp., and palm trees.

For the study of spatial variability, in each management system, a regular grid of $100 \mathrm{~m}^{2}$ (10x10 $\mathrm{m})$ was settled. The sampling system used consisted of three grids of regular spacing of 2.5 meters, with 25 georeferenciated points in the UTM system with submetric precision (DGPS - Trimble-Pro XT model). At each point, soil samples were collected at the depth of $0-0.10 \mathrm{~m}$. In each sample the following constituents of labile SOM were determined: free light fraction (FLF), forms of labile $\mathrm{C}$ and $\mathrm{N}$ soluble in water (Clab and Nlab) and content of glomalin. Besides, the textural fractions (sand, silt, and clay), $\mathrm{pH}$ in water, and chemical attributes (organic carbon, total $\mathrm{N}, \mathrm{Ca}, \mathrm{Mg}, \mathrm{Al}, \mathrm{P}, \mathrm{K}$, and CEC-cation exchange capacity) were also determined. The SMB and soil respiration were determined in 15 of the 25 points.

After collecting, soil samples were air dried, hand grinded, homogenized and sieved in $2.0 \mathrm{~mm}$ mesh for chemical, physical and biological analyses. The soil microbial biomass for carbon (SMB-C) and nitrogen (SMB-N) was determined using the method of fumigation extraction, proposed by VANCE et al. (1987) and TATE et al. (1988), with adjustments proposed by De-Polli and Guerra (1999). Basal soil respiration was determined in accordance with the methodology 
proposed by JENKINSON and POWLSON (1976) through the quantification of the evolution of $\mathrm{CO}_{2}$ accumulated during five days of incubation. The specific respiration or metabolic quotient $\left(\mathrm{qCO}_{2}\right.$ index) was determined according to ANDERSON and DOMSCH (1990).

The labile soil carbon and nitrogen components soluble in hot water were determined using the method of extraction in autoclave at $100{ }^{\circ} \mathrm{C}$, adapted from SPARLING et al. (1998) and BAKER et al. (1998). The free light fraction of organic matter was obtained by the procedure proposed by SoHI et al. (2001), as suggested by JANZEN et al. (1992). The quantification of total glomalin, a glycoprotein found in mycorrhizal fungi, was performed using the test of BRADFORD (1976), modified by Wright and UpADHYAYA (1998). Total glomalin-related soil protein (T-GRSP) was extracted by repeated cycles with $50 \mathrm{mM}$ citrate of sodium, $\mathrm{pH}$ 8.0 , by autoclaving at $121^{\circ} \mathrm{C}$ for $60 \mathrm{~min}$. The extraction of glomalin continued until the supernatant content of glomalin was $2 \mathrm{mg} \mathrm{ml}^{-1}$ (minimum level of detection). Extracts from each cycle were pooled and centrifuged at 10,000 $\mathrm{g}$ for $10 \mathrm{~min}$ to remove residual soil particles. Protein content was determined by Bradford assay (Sigma-Aldrich, Inc.) with bovine serum albumin as the standard. GRSP analyses were carried out on soil from two subsamples for each replicate.

The textural fractions (sand, silt, and clay), $\mathrm{pH}$ in water, and chemical attributes (organic carbon, $\mathrm{Ca}$, $\mathrm{Mg}, \mathrm{Al}, \mathrm{P}, \mathrm{K}$, and CEC-Cation Exchange Capacity) was determined according to EMBRAPA (1997). The total $\mathrm{N}$ was determined by BREMNER and MuLVANEY (1982).

To run the statistical analyses, first of all a descriptive analysis (minimum, maximum, mean, kurtosis, assimetry, CV, and standard error) was conducted to assess the pattern of distribution of data frequency, detecting anomalous values (Boxplot test) as well as the Pearson correlation between the variables through software XLSTAT 7.5 (ADINSOFT, 2004). GEOSTAT software (VIEIRA et al., 1983) was used to determine the spatial continuity (experimental semivariograms), to evaluating the most proper model to interpolation (cross-validation), as well as to interpolation by ordinary kriging. The maps generated by ordinary kriging covered an area of $100 \mathrm{~m}^{2}$ with $1 \times 1 \mathrm{~m}$ resolution. The file with interpolated data was exported to the program SURFER 7.02 (GOLDEN SOFTWARE, 2000) for better representation of the variability of attributes.

\section{RESULTS AND DISCUSSION}

\section{Descriptive statistical analysis}

The forest garden area presents the highest values of microbial biomass and labile constituents of soil organic matter (SOM) (Table 1). The lower range of temperature and humidity as well as the highest input of SOM, provides a more favorable environment for microbial activity and cycling of nutrients from the SOM in this kind of area (BANDICK and Dick, 1999; BOPAIAH and SHETTI, 1991; ORCHARD and COOK, 1983).

The mean of carbon content of soil microbial biomass (SMB-C) in the area of pasture is higher than in the area of alley cropping. The opposite occurs with the mean of nitrogen content in the soil microbial biomass (SMB-N), with higher values for thearea of alley cropping. This result has influenced the mean of $\mathrm{C} / \mathrm{N}$ ratio of the microbial biomass $(\mathrm{C} / \mathrm{Nmic})$, with lower relationship found in the alley cropping area (Table 1). This indicates higher conservation of nitrogen in this system through the incorporation of $\mathrm{C}$ and $\mathrm{N}$ in the microbial pool that can be a source of this nutrient for crops. Although the process of immobilization is sometimes considered a negative factor for crop production, in certain situations may be favorable because it is a temporary process and, therefore, consisting of potential reservoir of nutrients for plants (PAUL and CLARK, 1996). The microbial biomass has an active role on the immobilization-mineralization process increasing or reducing the availability of nutrients for plants (DUDA, 2000).

The mean of $\mathrm{C} / \mathrm{N}$ ratio was higher in the area of pasture (Table 1). According to Heal et al. (1997), this is a characteristic of this type of vegetation, with higher content of lignin, polyphenols and rigid structures. These characteristic also explain the higher amounts of free light fraction of SOM in pasture area than alley crops.

Evaluating the mean values of labile fractions (labile C, labile N and glomalin), stock of SOM (C and $\mathrm{N})$ and CEC, the system of alley cropping showed higher levels than pasture and lower than forest garden (Table 1). Since the management history of the alley cropping area included soil plowing, the $\mathrm{qCO}_{2}$ has remained higher than in areas of perennial crops (pasture and forest garden). Despite the fact that the system of alley cropping have a higher input of organic matter, reflecting positively on the stock of SOM including in its labile compartment, the efficiency of this management with intensive plowing can be questioned on the point of view of soil conservation since higher $\mathrm{qCO}_{2}$ is an indicative of a certain instability in the $\mathrm{C}$ flow. Due to the above reasons, in general, the forest garden area showed higher mean value of free light fraction (FLF), stocks of SOM (C and N), CEC and labile constituents of soil organic matter (SMB-C, SMB-N, Clab, Nlab and glomalin) (Table 1).

The mean of clay content in the area of alley cropping and pasture was similar (4 and $2 \%$ respectively) being different from the orchard garden area $(13 \%)$ (Table 1). It is worth emphasizing that in the area of 
Table 1. Summary of statistics values for microbial biomass, constituents of labile SOM, and physical attributes of soil

\begin{tabular}{|c|c|c|c|c|c|c|c|}
\hline Alley cropping & Minimum & Maximum & Mean & Kurtosis & Assimetry & CV (\%) & Standard error \\
\hline SMB-C & 36 & 93 & 61 & -1.3 & 0.3 & 32 & 5.0 \\
\hline SMB-N & 24 & 47 & 35 & 0.2 & 0.2 & 17 & 1.6 \\
\hline $\mathrm{C} / \mathrm{Nmic}$ & 1 & 3 & 2 & 1.8 & 1.1 & 30 & 0.1 \\
\hline Labile C & 438 & 712 & 571 & 0.4 & -0.1 & 12 & 18.3 \\
\hline Labile $\mathrm{N}$ & 61 & 98 & 83 & -0.9 & -0.4 & 14 & 3.1 \\
\hline Respiration & 0.3 & 0.8 & 0.5 & 0.0 & 0.3 & 28 & 0.0 \\
\hline $\mathrm{qCO}_{2}$ & 4 & 16 & 10 & 0.0 & 0.3 & 33 & 0.8 \\
\hline C & 5.4 & 9.2 & 6.9 & 1.6 & 0.7 & 14 & 0.2 \\
\hline $\mathrm{N}$ & 0.8 & 1.8 & 1.1 & 0.6 & 1.1 & 28 & 0.1 \\
\hline $\mathrm{C} / \mathrm{N}$ & 3 & 10 & 6 & 0.4 & 0.4 & 28 & 0.5 \\
\hline FLF & 0.011 & 0.034 & 0.018 & 1.2 & 1.1 & 36 & 0.0 \\
\hline Clay & 2 & 11 & 4 & 2.9 & 1.5 & 56 & 0.65 \\
\hline Sand & 79 & 90 & 87 & 1.6 & -1.5 & 4 & 0.90 \\
\hline Glomalin & 1.4 & 2.6 & 2.0 & -1.2 & 0.0 & 20 & 0.1 \\
\hline CEC & 5.4 & 7.0 & 6.1 & -1.0 & 0.4 & 8 & 0.1 \\
\hline Moisture & 6.9 & 10.8 & 8.6 & -0.1 & 0.3 & 12 & 0.3 \\
\hline Pasture & Minimum & Maximum & Mean & Kurtosis & Assimetry & CV (\%) & Standard error \\
\hline SMB-C & 54 & 176 & 102 & -0.4 & 0.7 & 35 & 9.2 \\
\hline SMB-N & 23 & 39 & 29 & -0.1 & 0.7 & 15 & 1.1 \\
\hline $\mathrm{C} / \mathrm{Nmic}$ & 2 & 5 & 4 & -1.4 & 0.1 & 30 & 0.3 \\
\hline Labile C & 337 & 512 & 412 & 0.0 & 0.3 & 12 & 12.5 \\
\hline Labile N & 50 & 149 & 76 & 4.7 & 2.0 & 33 & 6.5 \\
\hline Respiration & 0.2 & 1.4 & 0.4 & 10.3 & 3.0 & 71 & 0.1 \\
\hline $\mathrm{qCO}_{2}$ & 2 & 8 & 4 & -0.4 & 0.8 & 49 & 0.5 \\
\hline C & 2.7 & 5.2 & 3.9 & 1.7 & 0.1 & 14 & 0.1 \\
\hline $\mathrm{N}$ & 0.3 & 1.0 & 0.5 & 1.9 & 1.4 & 39 & 0.0 \\
\hline $\mathrm{C} / \mathrm{N}$ & 4 & 13 & 9 & -1.4 & -0.2 & 33 & 0.8 \\
\hline FLF & 0.015 & 0.069 & 0.027 & 8.8 & 2.7 & 48 & 0.00 \\
\hline Clay & 1 & 3 & 2 & -1.4 & -0.4 & 46 & 0.2 \\
\hline Sand & 92 & 95 & 94 & -0.3 & 0.0 & 1 & 0.2 \\
\hline Glomalin & 0.5 & 1.3 & 0.8 & 2.6 & 1.4 & 27 & 0.1 \\
\hline CEC & 3.1 & 5.4 & 4.1 & -0.5 & 0.2 & 17 & 0.2 \\
\hline Moisture & 1.1 & 2.4 & 1.8 & -1.0 & -0.4 & 23 & 0.1 \\
\hline Forest garden & Minimum & Maximum & Mean & Kurtosis & Assimetry & CV (\%) & Standard error \\
\hline SMB-C & 120 & 375 & 225 & 0.0 & 0.7 & 33 & 19.4 \\
\hline SMB-N & 34 & 63 & 47 & 0.4 & 0.5 & 16 & 2.0 \\
\hline C/Nmic & 3 & 8 & 5 & 0.5 & 0.8 & 29 & 0.4 \\
\hline Labile C & 614 & 2421 & 1202 & 2.8 & 1.4 & 38 & 117.8 \\
\hline Labile N & 93 & 293 & 166 & 1.4 & 1.0 & 31 & 13.5 \\
\hline Respiration & 0.0 & 1.7 & 1.0 & 2.9 & -0.8 & 38 & 0.1 \\
\hline $\mathrm{qCO}_{2}$ & 0 & 7 & 5 & 1.4 & -0.9 & 39 & 0.5 \\
\hline C & 8.5 & 19.2 & 12.0 & 1.6 & 1.2 & 23 & 0.7 \\
\hline $\mathrm{N}$ & 1.1 & 2.8 & 1.9 & -0.9 & 0.2 & 27 & 0.1 \\
\hline $\mathrm{C} / \mathrm{N}$ & 5 & 10 & 7 & 2.7 & 1.5 & 19 & 0.3 \\
\hline FLF & 0.022 & 0.177 & 0.067 & 1.5 & 1.3 & 64 & 0.01 \\
\hline Clay & 8 & 24 & 13 & -0.6 & 0.7 & 41 & 1.4 \\
\hline Sand & 53 & 81 & 73 & 4.3 & -1.6 & 9 & 1.8 \\
\hline Glomalin & 2.2 & 5.1 & 3.6 & -1.0 & 0.2 & 26 & 0.2 \\
\hline CEC & 7.6 & 15.3 & 10.8 & 1.1 & 0.6 & 18 & 0.5 \\
\hline Moisture & 6.7 & 18.3 & 11.6 & -0.3 & 0.7 & 29 & 0.9 \\
\hline
\end{tabular}

SMB-C, SMB-N: $\mathrm{C}$ and $\mathrm{N}$ of soil microbial biomass; C/Nmic: microbial C and $\mathrm{N}$ ratio; $\mathrm{qCO}_{2}$ : metabolic quotient; $\mathrm{C} / \mathrm{N}$ : soil $\mathrm{C}$ and $\mathrm{N}$ ratio; CEC: moisture cation exchange capacity; FLF: free light fraction; SMB-C, labile C: $\mathrm{mg} \mathrm{C} \mathrm{kg}^{-1}$ soil; SMB-N, labile N: mg N kg-1 solo;

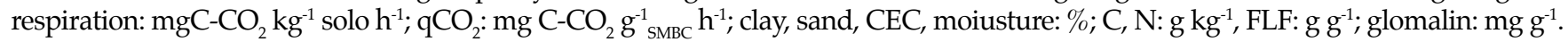


Table 2. Symmetrical linear correlation matrix of Pearson (r) between the attributes studied

\begin{tabular}{|c|c|c|c|c|c|c|c|c|c|c|c|c|c|c|c|c|}
\hline Alley cropping & SMB-C & SMB-N & $\mathrm{C} / \mathrm{Nmic}$ & Labile C & Labile N & Respiration & $\mathrm{qCO}_{2}$ & $\mathrm{C}$ & $\mathrm{N}$ & $\mathrm{C} / \mathrm{N}$ & FLF & Clay & Sand & Glomalin & CEC & Moisture \\
\hline SMB-C & 1.00 & & & & & & & & & & & & & & & \\
\hline SMB-N & 0.49 & 1.00 & & & & & & & & & & & & & & \\
\hline $\mathrm{C} / \mathrm{Nmic}$ & 0.82 & -0.09 & 1.00 & & & & & & & & & & & & & \\
\hline Labile C & 0.70 & 0.12 & 0.70 & 1.00 & & & & & & & & & & & & \\
\hline Labile N & 0.61 & 0.53 & 0.31 & 0.41 & 1.00 & & & & & & & & & & & \\
\hline Respiration & 0.44 & -0.37 & 0.76 & 0.58 & 0.05 & 1.00 & & & & & & & & & & \\
\hline $\mathrm{qCO}_{2}$ & -0.61 & -0.70 & -0.26 & -0.22 & -0.35 & 0.29 & 1.00 & & & & & & & & & \\
\hline C & 0.67 & 0.34 & 0.51 & 0.72 & 0.68 & 0.29 & -0.41 & 1.00 & & & & & & & & \\
\hline $\mathrm{N}$ & -0.17 & -0.13 & -0.13 & -0.03 & 0.02 & 0.06 & 0.28 & -0.02 & 1.00 & & & & & & & \\
\hline $\mathrm{C} / \mathrm{N}$ & 0.45 & 0.29 & 0.33 & 0.32 & 0.33 & 0.03 & -0.43 & 0.53 & -0.82 & 1.00 & & & & & & \\
\hline FLF & 0.15 & -0.02 & 0.17 & 0.28 & 0.01 & 0.15 & -0.07 & 0.35 & -0.34 & 0.58 & 1.00 & & & & & \\
\hline Clay & 0.47 & 0.15 & 0.40 & 0.62 & 0.30 & 0.24 & -0.35 & 0.64 & -0.19 & 0.50 & 0.68 & 1.00 & & & & \\
\hline Sand & -0.44 & -0.29 & -0.26 & -0.37 & -0.46 & -0.11 & 0.21 & -0.46 & -0.10 & -0.16 & -0.36 & -0.63 & 1.00 & & & \\
\hline Glomalin & 0.56 & 0.20 & 0.51 & 0.77 & 0.30 & 0.54 & -0.26 & 0.72 & -0.03 & 0.28 & 0.18 & 0.59 & -0.19 & 1.00 & & \\
\hline $\mathrm{CEC}$ & 0.33 & -0.19 & 0.53 & 0.23 & -0.06 & 0.19 & -0.25 & 0.14 & -0.70 & 0.69 & 0.50 & 0.22 & -0.01 & -0.04 & 1.00 & \\
\hline Moisture & 0.08 & 0.06 & 0.03 & -0.04 & -0.06 & 0.21 & -0.04 & -0.16 & 0.47 & -0.55 & -0.48 & -0.06 & -0.16 & 0.18 & -0.59 & 1.00 \\
\hline Pasture & SMB-C & SMB-N & C/Nmic & Labile C & Labile N & Respiration & $\mathrm{qCO}_{2}$ & C & $\mathrm{N}$ & $\mathrm{C} / \mathrm{N}$ & FLF & Clay & Sand & Glomalin & CEC & Moisture \\
\hline SMB-C & 1.00 & & & & & & & & & & & & & & & \\
\hline SMB-N & 0.45 & 1.00 & & & & & & & & & & & & & & \\
\hline $\mathrm{C} / \mathrm{Nmic}$ & 0.87 & -0.02 & 1.00 & & & & & & & & & & & & & \\
\hline Labile C & -0.02 & 0.30 & -0.22 & 1.00 & & & & & & & & & & & & \\
\hline Labile N & 0.62 & 0.48 & 0.37 & 0.35 & 1.00 & & & & & & & & & & & \\
\hline Respiration & 0.52 & 0.61 & 0.22 & 0.46 & 0.71 & 1.00 & & & & & & & & & & \\
\hline $\mathrm{qCO}_{2}$ & -0.18 & 0.33 & -0.42 & 0.31 & 0.28 & 0.69 & 1.00 & & & & & & & & & \\
\hline C & 0.50 & 0.30 & 0.40 & -0.10 & 0.54 & 0.11 & -0.16 & 1.00 & & & & & & & & \\
\hline $\mathrm{N}$ & 0.67 & 0.51 & 0.46 & 0.10 & 0.66 & 0.56 & 0.05 & 0.18 & 1.00 & & & & & & & \\
\hline $\mathrm{C} / \mathrm{N}$ & -0.38 & -0.27 & -0.29 & -0.01 & -0.24 & -0.29 & 0.08 & 0.25 & -0.86 & 1.00 & & & & & & \\
\hline FLF & 0.50 & 0.56 & 0.20 & 0.57 & 0.76 & 0.90 & 0.57 & 0.23 & 0.53 & -0.18 & 1.00 & & & & & \\
\hline Clay & 0.39 & 0.33 & 0.28 & -0.04 & 0.10 & 0.34 & 0.11 & 0.12 & 0.22 & -0.13 & 0.31 & 1.00 & & & & \\
\hline Sand & 0.20 & -0.02 & 0.21 & 0.47 & 0.12 & 0.23 & -0.07 & -0.38 & 0.28 & -0.43 & 0.23 & -0.03 & 1.00 & & & \\
\hline Glomalin & 0.34 & 0.08 & 0.31 & -0.25 & 0.40 & -0.03 & -0.13 & 0.67 & 0.31 & -0.02 & 0.14 & 0.01 & -0.13 & 1.00 & & \\
\hline CEC & 0.60 & 0.35 & 0.45 & 0.22 & 0.77 & 0.48 & 0.11 & 0.79 & 0.37 & 0.11 & 0.62 & 0.25 & -0.14 & 0.48 & 1.00 & \\
\hline Moisture & 0.44 & 0.57 & 0.22 & -0.17 & 0.33 & 0.55 & 0.39 & 0.47 & 0.37 & -0.10 & 0.45 & 0.48 & -0.45 & 0.13 & 0.42 & 1.00 \\
\hline Forest garden & SMB-C & SMB-N & $\mathrm{C} / \mathrm{Nmic}$ & Labile C & Labile N & Respiration & $\mathrm{qCO}_{2}$ & C & $\mathrm{N}$ & $\mathrm{C} / \mathrm{N}$ & FLF & Clay & Sand & Glomalin & CEC & Moisture \\
\hline SMB-C & 1.00 & & & & & & & & & & & & & & & \\
\hline SMB-N & 0.51 & 1.00 & & & & & & & & & & & & & & \\
\hline $\mathrm{C} / \mathrm{Nmic}$ & 0.85 & -0.01 & 1.00 & & & & & & & & & & & & & \\
\hline Labile C & 0.26 & 0.55 & 0.05 & 1.00 & & & & & & & & & & & & \\
\hline Labile N & 0.44 & 0.69 & 0.15 & 0.82 & 1.00 & & & & & & & & & & & \\
\hline Respiration & 0.42 & 0.39 & 0.29 & 0.42 & 0.50 & 1.00 & & & & & & & & & & \\
\hline $\mathrm{qCO}_{2}$ & -0.41 & -0.08 & -0.40 & 0.05 & 0.06 & 0.63 & 1.00 & & & & & & & & & \\
\hline $\mathrm{C}$ & 0.41 & 0.60 & 0.18 & 0.88 & 0.83 & 0.41 & -0.07 & 1.00 & & & & & & & & \\
\hline $\mathrm{N}$ & 0.55 & 0.55 & 0.36 & 0.62 & 0.64 & 0.31 & -0.28 & 0.84 & 1.00 & & & & & & & \\
\hline $\mathrm{C} / \mathrm{N}$ & -0.36 & -0.14 & -0.35 & 0.12 & 0.01 & 0.05 & 0.40 & -0.06 & -0.57 & 1.00 & & & & & & \\
\hline FLF & 0.14 & 0.49 & -0.08 & 0.84 & 0.78 & 0.19 & -0.04 & 0.79 & 0.53 & 0.16 & 1.00 & & & & & \\
\hline Clay & 0.54 & 0.63 & 0.28 & 0.48 & 0.74 & 0.41 & -0.08 & 0.55 & 0.62 & -0.36 & 0.38 & 1.00 & & & & \\
\hline Sand & -0.45 & -0.72 & -0.14 & -0.74 & -0.90 & -0.48 & -0.03 & -0.84 & -0.70 & 0.09 & -0.70 & -0.87 & 1.00 & & & \\
\hline Glomalin & 0.23 & 0.40 & 0.07 & 0.73 & 0.67 & 0.31 & 0.03 & 0.80 & 0.53 & 0.25 & 0.80 & 0.12 & -0.53 & 1.00 & & \\
\hline CEC & 0.47 & 0.69 & 0.20 & 0.80 & 0.79 & 0.27 & -0.24 & 0.93 & 0.79 & -0.09 & 0.76 & 0.64 & -0.88 & 0.72 & 1.00 & \\
\hline Moisture & 0.85 & 0.62 & 0.64 & 0.46 & 0.72 & 0.54 & -0.20 & 0.63 & 0.72 & -0.37 & 0.33 & 0.84 & -0.78 & 0.31 & 0.67 & 1.00 \\
\hline
\end{tabular}

Values in boldface shown significant level at $5 \%$.

forest garden, the highest amount of clay is strongly influenced by the occurrence of the activity of termites, which brings more material from deeper soil horizon to the surface layers. According to MoreIRA and SIQUEIRA (2002) a greater accumulation of microbial biomass is expected in soils with higher clay content (higher water and nutrient retention and less variation in temperature). Lower mean value of soil moisture $(1.8 \%)$ in the pasture area (Table1) was observed. This is a consequence of its sandy texture combined with a period of low rainfall (Table 1). Similar values of soil moisture for this same area of pasture were found by VILLELA (2007). 
According to WEBSTER (2001), attributes that have asymmetry ranging from 0 to around \pm 0.5 have normal distribution. Considering that criterion, it appears that the system of alley cropping probably presents greater number of attributes with distribution closer to the normal (SMB-C, SMB-N, labile $\mathrm{C}$ and $\mathrm{N}$, respiration, $\mathrm{qCO}_{2}, \mathrm{C} / \mathrm{N}$, soil moisture, glomalin, and CEC) (Table 1). Besides, it appears that except for sand content in the three management systems, and CEC in alley cropping, the coefficient of variation showed medium or high values (> 10\%) (PImentel-Gomes, 1984). The largest coefficient of variation $(\mathrm{CV})$ values for the attributes related to microbial biomass and labile components of SOM are expected, since they have high sensitivity to edapho-climatic variation showing more erratic behavior.

Table 2 shows the linear correlation coefficients of Pearson (r), between the physical attributes and microbial biomass and constituents of labile SOM. In studies of spatial variability through geostatistics, the detection of significant correlation between the attributes is especially important to improve the interpolation of attributes of more difficult analyses (SMB and labile SOM) from others of easier analyses (organic carbon and texture) through ordinary co-kriging. At table 2 we can note that the organic $\mathrm{C}$ was the attribute, relatively easier to measure, which most significantly correlated with SMB and labile constituents (SMB-C, SMB-N, labile N and C, FLF, and glomalin), in alley crops and forest garden area. Among the systems evaluated pasture area is the one with fewer attributes for SMB and labile constituents of SOM correlated with organic $\mathrm{C}$ and texture. The forest garden showed greater number of values of SMB and labile SOM positively correlated with the clay content (Table 2). This behavior is expected, because in the forest garden area higher level of clay associated with the activity of termites was found, resulting also in higher values of soil CEC, specific surface, SMB and labile SOM. Although there are positive correlations between clay and $\mathrm{SMB}$ and labile constituents of SOM on the forest area, it should be noted that this kind of land use favors the highest levels of those attributes.

According to Powlson et al. (1987), part of the observed variation in the quantity of microbial biomass is associated with input of organic matter to soil. From Tables 1 and 2 we can have an understanding on the variation of the attributes of microbial biomass and labile constituents of SOM. Areas with greater input of organic matter present higher values of SMB and labile constituents as well as greater correlation of these attributes with organic $C$.

\section{Analysis of Spatial Variability}

Table 3 shows the parameters for the models fitted to the experimental semivariograms of the attributes studied. In the area of alley cropping the attributes that showed spatial dependence were C, FLF, SMB-N and respiration, and the spherical model was fitted to these attributes. In the area of pasture $\mathrm{C}$ and microbial $\mathrm{C} / \mathrm{N}$ ratio showed spatial dependence and the Gaussian model was fitted to these attributes. The range value for SMB-N was $5.5 \mathrm{~m}$ estimated by the semivariogram in the area of alley cropping (Table 3). This demonstrates high sensitivity of this variable to the applied management, where the spacing between rows of $6 \mathrm{~m}$ for Gliricidia, probably, influenced the pattern of spatial variability of SMB-N. Since Gliricidia is a $\mathrm{N}_{2}$ fixing tree legume in association with rhizobium bacteria the falling leaves concentrates under-crown area generating a gradient of organic matter and SMB-N between the cropping rows.

The bush garden area did not show spatial dependence for the attributes of microbial biomass and labile constituents of SOM. The random pattern of variability of SMB and labile constituents in the area of bush garden is due, probably, to the random input to the soil of organic matter from forest litter (different species, size, and amount) where the trees were settled originally in the area in a random distribution. Also, with the soil protection provided by the trees the

Table 3. Theoretical estimated values of semivariograms

\begin{tabular}{|c|c|c|c|c|c|c|}
\hline Attributes** & Model* & $\mathrm{C}_{\mathrm{o}}$ & $\mathrm{C}_{1}$ & $\begin{array}{c}\mathrm{C}_{\mathrm{o}} /\left(\mathrm{C}_{\mathrm{o}}+\mathrm{C}_{1}\right) * 100 \\
(\%)\end{array}$ & $\begin{array}{c}\text { Range } \\
(\mathrm{m})\end{array}$ & $\mathrm{r}^{2}$ \\
\hline \multicolumn{7}{|c|}{ Alley cropping } \\
\hline $\mathrm{C}$ & Espherical & 0 & 0.69 & 0 & 13 & 0.79 \\
\hline FLF & Espherical & 0.0000004 & 0.00005 & 0.79 & 7.9 & 0.91 \\
\hline SMB-N & Espherical & 0 & 35.5 & 0 & 5.5 & 0.47 \\
\hline Respiration & Espherical & 0.016 & 0.009 & 64 & 13.4 & 0.49 \\
\hline \multicolumn{7}{|c|}{ Pasture } \\
\hline $\mathrm{C}$ & Gaussian & 0.15 & 0.24 & 38.5 & 10.3 & 0.87 \\
\hline $\mathrm{C} / \mathrm{Nmic}$ & Gaussian & 0.53 & 1.16 & 31.4 & 13.1 & 0.80 \\
\hline
\end{tabular}

* Selected models by cross-validation (jacknife); $\mathrm{C}_{0}$ : nugget effect; $\mathrm{C}_{1}$ : sill.

${ }^{* *}$ C: organic carbon; FLF: free light fraction; SMB-N: nitrogen of soil microbial biomass; C/Nmic: microbial carbon/nitrogen ratio. 
variation in temperature and humidity were lower reducing spots of variability in terms of soil moisture and temperature that would create extreme values of attributes that affect the SMB and the dynamics of SOM. These results corroborate with HARGREAVES et al. (2003) that studied the spatial variability of microbial biomass carbon in the jungle area converted to forest after being an arable field, also discovered that the results of the semivariogram analysis revealed no spatial dependence. PAZ-GonZÁLEZ et al. (2000) found lower nugget effect of variables Corg and cation exchange capacity (CEC) in crop area under rotational system with pasture than in areas under natural vegetation suggesting that the crop area has shows greater continuity in the semivariogram. This paper presents data similar to those found by these authors. The alley cropping area shows a higher number of variables of microbial biomass and labile components with spatial dependence and low nugget effect, indicating that the management as alley cropping is changing the pattern of spatial variability of these attributes (Figure 1).
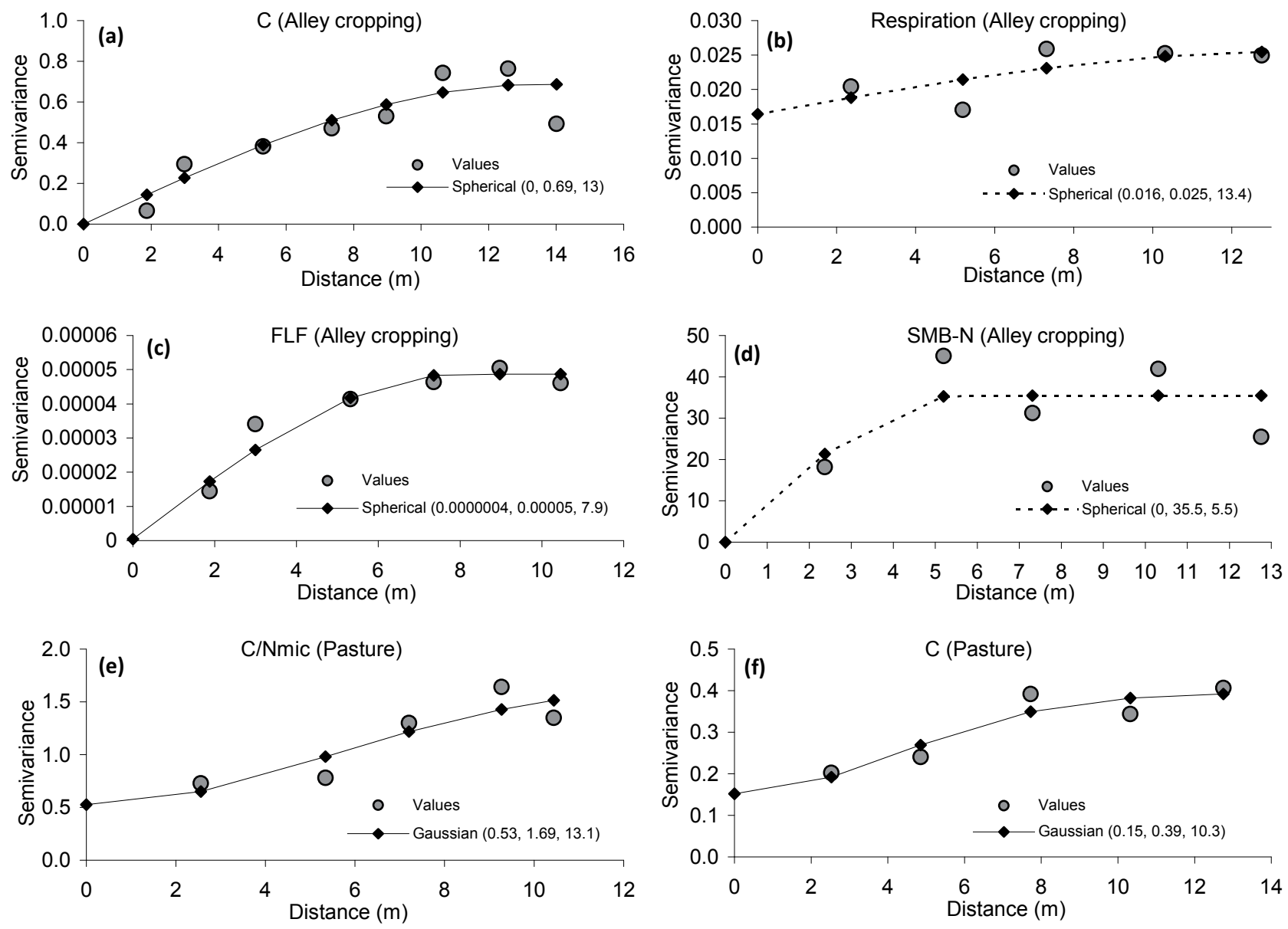

Figure 1. Semivariograms of $\mathrm{C}$ in Alley cropping (a), respiration (b), free light fraction (FLF c), N of soil microbial biomass (SMB-N, d), microbial carbon/ nitrogen ratio (C/Nmic, e) and of $\mathrm{C}$ in pasture (f). Values between parentheses correspond to nugget effect $\mathrm{C}_{0^{\prime}}$ contribution $\mathrm{C}_{1}$ and range of the fitted model, respectively.
However, the possibility of induction of spatial dependence through different managements, as the alley cropping system does not apply to all attributes related to soil organic matter. The content of glomalin, for example, did not present spatial dependence in any of managements evaluated.

\section{Maps of spatial variability of clay, C, microbial biomass and labile constituents of SOM.}

The maps of spatial variability of $\mathrm{C}$, respiration, FLF, and SMB-N in the area of alley cropping are shown in Figures 2a, b and 3a, b, respectively. Through visual assessment, we can see the similarity of behavior between $\mathrm{C}$ and $\mathrm{SMB}-\mathrm{N}$ and that the respiration tends to behave in opposite manner. This pattern is most easily local activities with greater microbial respiratory level present less C and SMB-N. The reverse pattern in this point of the area of alley cropping indicates that the efficiency of soil microbial activity is low and that the soil micro-organisms are under a factor of stress, since detected in the upper right corner of those maps, where 
(a)

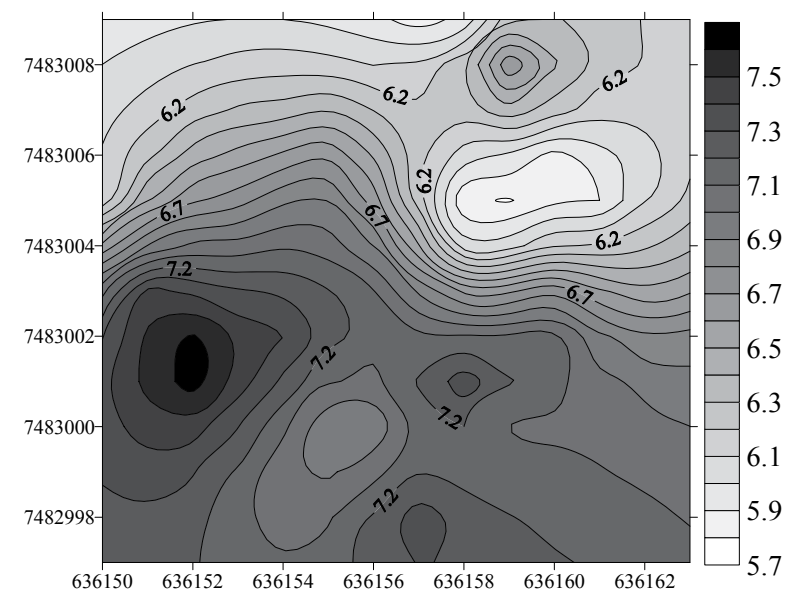

(b)

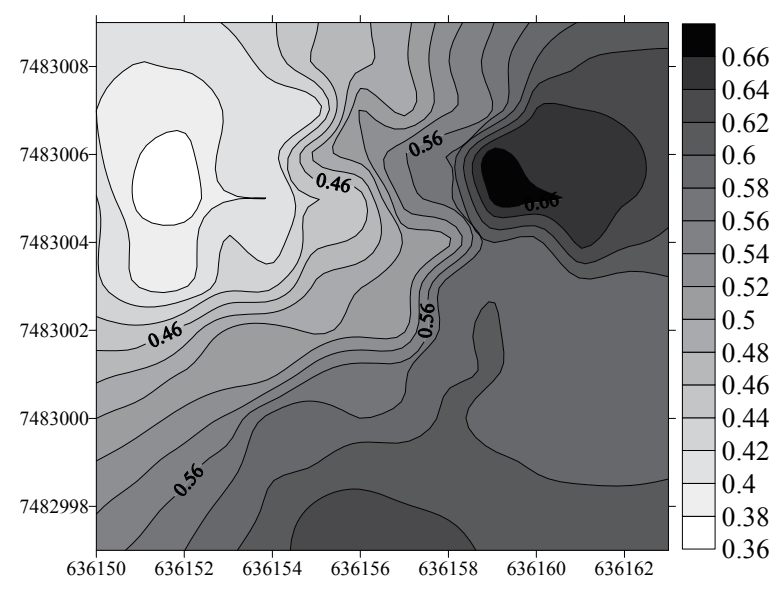

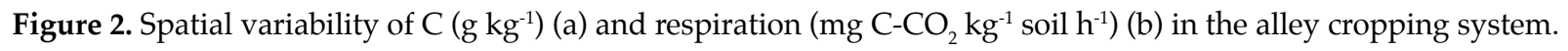

(a)

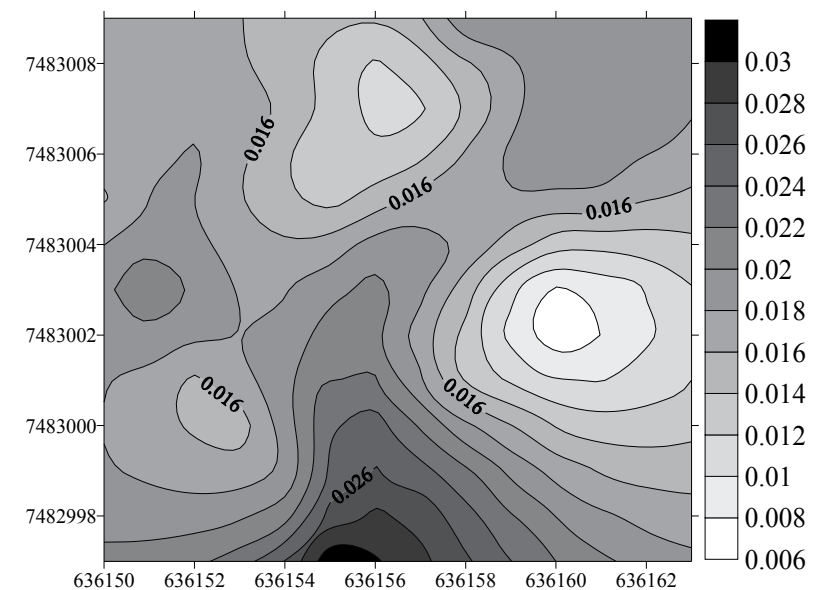

(b)

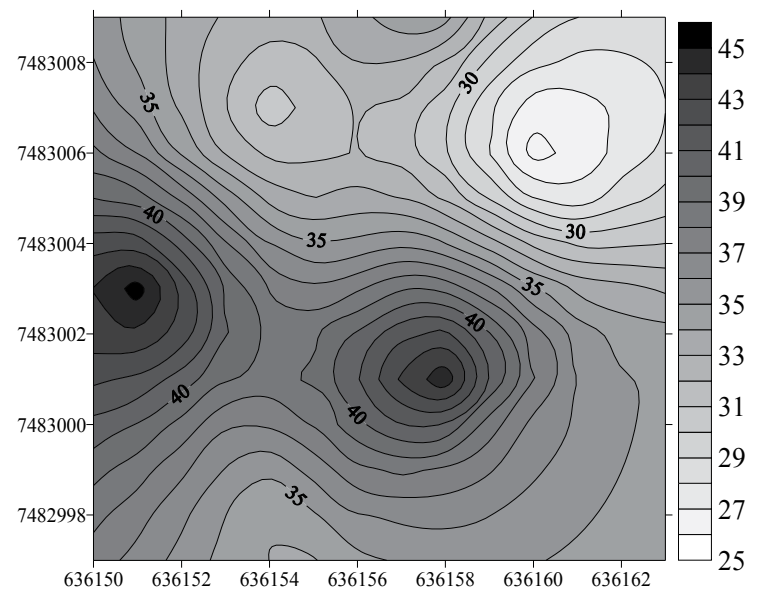

Figure 3. Spatial variability of FLF $\left(\mathrm{g} \mathrm{g}^{-1}\right)(\mathrm{a})$ and SMB-N $\left(\mathrm{mg} \mathrm{kg}^{-1}\right)(\mathrm{b})$ in alley cropping system.

(a)

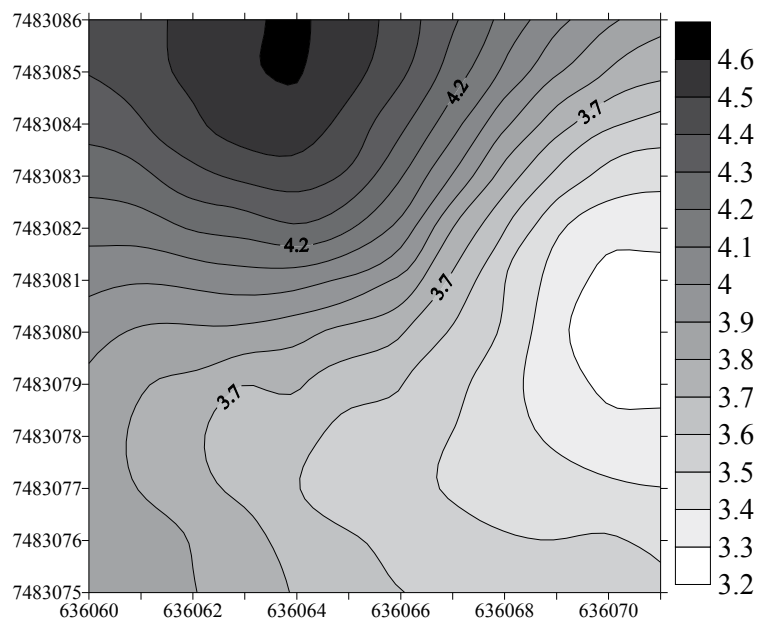

(b)

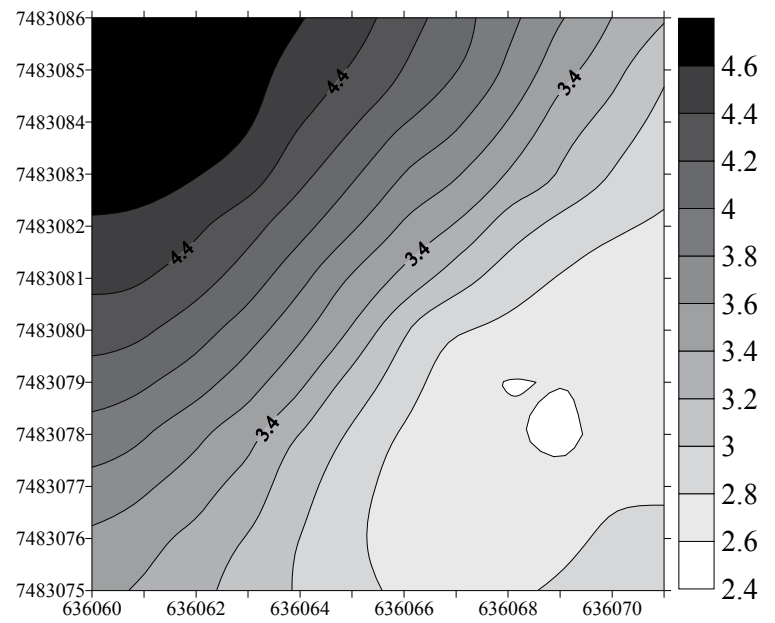

Figure 4. Spatial variability of $C\left(\mathrm{~g} \mathrm{~kg}^{-1}\right)(\mathrm{a})$ and the $\mathrm{C} / \mathrm{Nmic}$ ratio $(\mathrm{b})$ in the pasture. 
an efficient microbial biomass releases less carbon in the form of $\mathrm{CO}_{2}$ by respiration (AquiNo et al., 2005). Regarding the FLF, it was not seen, visually, a pattern of systematic variability as seen in the other attributes.

The detection of regions with behavior directly and inversely proportional, such as $\mathrm{C}$ and SMB-N, and those with respiration, respectively, shows that the geostatistics tool extends the possibility of examining the phenomena in a given area.

Figure $4 a, b$ refers to the maps of $C$ and microbial $\mathrm{C} / \mathrm{N}$ ratio $(\mathrm{C} / \mathrm{Nmic})$ respectively, in the area of pasture. There is a similar pattern of spatial variability of these attributes, or areas with higher levels of $\mathrm{C}$ promoted greater microbial $\mathrm{C} / \mathrm{N}$ ratio. This site has been under pasture for about two decades and since then has not received other sort of management. This pattern of regular pasture cover could be the cause of the gradient of $\mathrm{C}$ and $\mathrm{C} / \mathrm{Nmic}$ been well associated.

\section{CONCLUSION}

Some attributes of microbial biomass and labile constituents of soil organic matter had spatial dependence, specifically in the areas with the highest anthropogenic activity such as in alley cropping and pasture areas. Considering the relative homogeneity of soil and topography of the areas examined, this result confirms the hypothesis that selective management of soil (extrinsic factor) induces spatial variability, in this case some attributes related to soil organic matter.

\section{ACKNOWLEDGEMENTS}

To CAPES for the awarded scholarships to the first author and $\mathrm{CNPq}$ and FAPERJ for financial aid to the research.

\section{REFERENCES}

ADDINSOFT. 2004. XLSTAT-PLS 1.8. Statistical software to MS Excel.

ALVARENGA, M.I.N.; SIQUEIRA, J.O.; DAVIDE, A.C. Teor de carbono, biomassa microbiana, agregação e Micorriza em solos de cerrado com diferentes usos. Ciência e Agrotecnologia, v.23, p.617-625, 1999.

ANDERSON, T.H.; DOMSCH, K.H. Application of ecophysiological quotients (qCO2 and qD) on microbial biomasses from soils of different cropping histories. Soil Biology and Biochemistry, v.22, p.251-255, 1990.

AQUINO, A.M.; SILVA, E.M.R.; SAGGIN JUNIOR, O.; RUMJANEK, N.; DE-POLLI, H.; REIS, V.M. A biota do solo e processos relevantes num novo contexto da agricultura. In: WADT, P.G.S. (Ed.). Manejo do solo e recomendação de adubação para o Estado do Acre. Rio Branco: Embrapa Acre, 2005. Cap.4. p.121-174.

ASSIS JUNIOR, S.L.; ZANUNCIO, J.C.; KASUYA, M.C.M.; COUTO, L.; MELIDO, R.C.N. Atividade microbiana do solo em sistemas agroflorestais, monoculturas, mata natural e área desmatada. Revista Árvore, v.27, p.35-41, 2003.

BAKER, A.D.; ZUBERER, D.A; WILDING, L.P. Inconsistence in methods for measuring bioavaliable carbon and microbial biomass in soil from the NRCS wet soil monitoring project. In: INTERNATIONAL WORKSHOP ON ASSESSMENT METHODSFORSOILCPOOLS, 1998, Columbus. Abstract and Program...Columbus: Ohio State University/ USDA,1998.

BANDICK, A.K.; DICK, R.P. Field management effects on soil enzymes activities. Soil Biology and Biochemistry, v.31, p.1471-1479, 1999.

BOPAIAH, B.M.; SHETTI, H.S. Soil microflora and biological activities in the rhizospheres and root regions of coconutbased multistoreyed cropping and coconut monocropping systems. Soil Biology and Biochemistry, v.17, p.297-302, 1991.

BRADFORD, M.M. A rapid and sensitive method for the quantitation of microgram quantities of protein utilizing the principle of protein-dye binding. Analytical Biochemistry, v.72, p.248-254, 1976

BREMNER, J. M.; MULVANEY, C. S. Nitrogen total. In: PAGE, A. L. (Ed.). Methods of soil analysis. Part 2. 2.ed. Madison: Soil Science Society of America, 1982. p.595-624.

CARVALHO, M.P.; TAKEDA E.Y.; FREDDI, O.S. Variabilidade espacial de atributos de um solo sob videira em Vitória Brasil (SP). Revista Brasileira de Ciência do Solo, v.27, p.695-703, 2003.

D'ANDRÉA, A.F.; SILVA, M.L.N.; CURI, N.; GUILHERME, L.R.G. Estoque de carbono e nitrogênio e formas de nitrogênio mineral em um solo submetido a diferentes sistemas de manejo. Pesquisa Agropecuária Brasileira, v.39, p.179-186, 2004.

DE-POLLI, H.; GUERRA, J.G.M. C, $\mathrm{N}$ e $\mathrm{P}$ na Biomassa Microbiana do Solo. In: SANTOS, G.A.; CAMARGO, F.A.O. (Ed.). Fundamentos da Matéria Orgânica do Solo. Porto Alegre: Genesis, 1999. p.389-411.

DUDA, G.P. Conteúdo de fósforo microbiano, orgânico e biodisponível em diferentes classes de solo. Seropédica: Universidade Federal Rural do Rio de Janeiro, 2000. 158p. Tese (Doutorado em Ciência do Solo) - Universidade Federal Rural do Rio de Janeiro, 2000.

EL SEBAI, T.; LAGACHERIE, B.; SOULAS, G.; MARTINLAURENT, F. Spatial variability of isoproturon mineralizing activity within an agricultural field: Geostatistical analysis of simple physicochemical and microbiological soil parameters. Environmental Pollution, v.145, p.680-690, 2007.

FRAISSE, C.W.; SUDDUTH, K.A.; KITCHEN, N.R.; FRIDGEN, J.J. Use of unsupervised clustering algorithms of delineating 
within-field management zones. St. Joseph: American Society of Agricultural Engineers, 1999. 121p.

GOLDEN SOFTWARE, Surfer V 7.02. Surface Mapping System, 2000. Colorado USA.

HALVORSON, J. J., SMITH, J. L., AND PAPENDICK, R. I. Issues of scale for evaluating soil quality. Journal of Soil and Water Conservation, v.52, n.1, p.26-30, 1997.

HARGREAVES, P.R.; BROOKES, P.C.; ROSS, G.J.S.; POULTON, P.R.; Evaluating soil microbial biomass carbon as an indicator of long-term environmental change. Soil Biology and Biochemistry, v.35 p.401-407, 2003.

HEAL, O.W.; ANDERSON, J.M.; SWIFT, M.T. Plant litter quality and decomposition: an historical overview. In: GADISH, G.; GILLER, K.E. (Eds). Driven by nature. Wallingfor : CAB International, 1997. p.3-32.

HOPMANS, P.; BAUHUS, J.; KHANNA, P.; WESTON, C. Carbon and nitrogen in Forest soils: Potential indicators for sustainable management of eucalypt forests in southeastern Austrália. Forest Ecology and Management, v.220, p.75-87, 2005.

ISAAKS, E. H., SIVASTAVA, R. M., Applied Geoestatistics. Oxford: Oxford University Press, 1989. 560p.

JANZEN,H.H.;CAMPBELL,C.A.;BRANDT,S.A.Lightfraction organic matter in soils from long-term crop rotations. Soil Science Society of America Journal, v.56, p.1799-1806, 1992.

JENKINSON, D.S.; POWLSON, D.S. The effects of biocidal treatments on metabolism in soil. V. Method for measuring soil biomass. Soil Biology and Biochemistry, v.8, p.209-213, 1976.

MALUCHE-BARETTA, C.R.D.; AMARANTE, C.V.T.; KLAUBERG FILHO, O. Análise multivariada de atributos do solo em sistemas convencional e orgânico de produção de maçãs. Pesquisa Agropecuária Brasileira, v.41 p.1531-1539, 2006.

MARCHIORI JUNIOR, M.; MELO, W.J. Alterações na matéria orgânica e na biomassa microbiana em solos de mata natural submetido a diferentes manejos. Pesquisa Agropecuária Brasileira, v.35, p.1177-1182, 2000.

MARTINAZZO, R.; SANTOS, D.R.; GATIBONI, L.C.; BRUNETTO, G.; KAMINSKI, J. Fósforo microbiano do solo sob sistema plantio direto em resposta à adição de fosfato solúvel. Revista Brasileira de Ciência do Solo, v.31, p.563-570, 2007.

MOREIRA, A.; MALAVOLTA, E. Dinâmica da matéria orgânica e da biomassa microbiana em solo submetido a diferentes sistemas de manejo na Amazônia Ocidental. Pesquisa Agropecuária Brasileira, v.39, p.1103-1110, 2004.

MOREIRA, F.M.S.; SIQUEIRA, J.O. Microbiologia e bioquímica do solo. Lavras: UFLA, 2002. 625p.
ORCHARD, V.; COOK, F. J. Relationship between soil respiration and soil moisture. Soil Biology and Biochemistry, v. 15, p.447-453, 1983.

PAUL, E.A.; CLARK, F.E. Soil microbiology and biochemistry. California: Academic Press, 1996. 340p.

PAZ-GONZÁLES, A.; VIEIRA, S.R.; TABOADA CASTRO, M.T. The effect of cultivation on the spatial variability of selected properties of an umbric horizon. Geoderma, v.97, p.273-292, 2000.

PIMENTEL-GOMES, F. A estatística moderna na pesquisa agropecuária. Piracicaba: Associação Brasileira para Pesquisa da Potassa e do Fosfato, 1984. 160 p.

POWLSON, D. S.; BROOKES, P. C.; CHRISTENSEN, B. T. Measurement of soil microbial biomass provides an early indication of changes in total soil organic matter due to straw incorporation. Soil Biology and Biochemistry, v.19, p.159-164, 1987.

SILVA, A.P.; LIBARDI, P.L.; VIEIRA, S.R. Variabilidade espacial da resistência à penetração de um Latossolo Vermelho-Escuro ao longo de uma transeção. Revista Brasileira de Ciência do Solo, v.13, p.1-5, 1989.

SOHI, S.; MAHIEU, N.; ARAH, J.R.M.; POWLSON, D.S.P.; MADARI, B. \& GAUNT, J.L. Procedure for isolating soil organic matter fractions suitable for modeling. Soil Science Society of America Journal, v.65, p.1121-1128, 2001.

SOUZA, E.D.; CARNEIRO, M.A.C.; PAULINO, H.B.; SILVA, C.A.; BUZETTI, S. Alterações nas frações do carbono em um neossolo quartzarênico submetido a diferentes sistemas de uso do solo. Acta Scientiarum Agronomy, v.28, p.305-311, 2006.

SPARLING, G. P., VOJVODC-VUKOVIC, M.; SCHIPPER, L. A. Hot-water-soluble $C$ as a simple measure of labile soil organic matter: the relationship with microbial biomass $\mathrm{C}$. Soil Biology and Biochemistry, v.30, p.1472-1479, 1998.

STOYAN, H., DE-POLLI, H., BOHM, S., ROBERTSON, G. P., PAUL, E. A. Spatial heterogeneity of soil respiration and related properties at the plant scale. Plant and Soil, v.222, p.203-214, 2000.

SWEZEY, S.L.; WERNER, M.R.; BUCHANAN, M.; ALLISON, J. Comparison of conventional and organic apple production systems during three years of conversion to organic management in coastal California. American Journal of Alternative Agriculture, v.13, p.162-180, 1998.

TATE, K.R.; ROSS, D.J.; FLETAM, C.W. A direct extraction method to estimate soil microbial C: effects of experimental variables and some different calibration procedures. Soil Biology and Biochemistry, v.20, p.329-335, 1988.

VANCE, E.D.; BROOKES, P.C.; JENKINSON, D.S. An extraction method for measuring soil microbial biomass $C$. Soil Biology and Biochemistry, v.19, p.703-707, 1987. 
VIEIRA, S.R.; HATFIELD, J.L.; NIELSEN, D.R.; BIGGAR, J.W. Geoestatistical Theory and Application to Variability of Some Agronomical Properties. Hilgardia, v.51, p.1-75, 1983.

VILLELA, A.L.O. Variabilidade Espacial da Qualidade Físico-Hídrica dos Solos de uma Unidade de Pesquisa em Produção Agroecológica. 2007. 55f. Dissertação (Mestrado em Ciência do Solo) - Universidade Federal Rural do Rio de Janeiro Seropédica.

WEBSTER, R.. Statistics to support soil research and their presentation. European Journal of Soil Science, v.52, 331-340, 2001.
WRIGHT, S. F.; UPADHYAYA, A. A survey of soils for aggregate stability and glomalin, a glycoprotein produced by hyphae of arbuscular mycorrhizal fungi. Plant and Soil, v.198, p. 97-107, 1998.

WRIGHT, S.F.; FRANKE-SNYDER, M.; MORTON, J.B.; UPADHYAYA, A. Timecourse study and partial characterization of a protein on hyphae of arbuscular mycorrhizal fungi during active colonization of roots. Plant and Soil, v.181, p.193-203, 1996. 
